\title{
ANALISIS SEKTOR INDUSTRI PERTANIAN \\ PADA MODEL CAPM
}

\author{
Andreas Kiky \\ Universitas Multimedia Nusantara \\ andreas.kiky@umn.ac.id
}

The most popular Asset Pricing that has been known for long time was CAPM. This model offers very simple approach and strong fundamental theory for financial literature. Base of previous research using time-series data, this model show very good explanation in explain variation of portfolio return. Aim of this research is to find some pattern in different industrial sector, especially agriculture sector.

\section{Keywords: CAPM, Empirical Evidence, Abnormal Return, Stock Return}

\section{Pendahuluan}

Pasar Modal Indonesia didirikan sejak tahun 1912 yang sampai saat ini telah berkembang sangat pesat dan tumbuh menjadi pusat perputaran roda ekonomi Indonesia.

Didukung oleh kuatnya infrastruktur dan membaiknya sistem serta kemudahan mengakses pasar modal, maka sekarang telah banyak investor-investor pemula yang mulai belajar dan melakukan perdagangan efek secara rutin.

Belakangan ini berkembangnya kekuatan baru di Asia membuat pasar modal di kawasan ASEAN tumbuh pesat. Indonesia merupakan salah satu dari negara yang mengalami pertumbuhan tersebut. Hal ini juga didukung oleh tumbuhnya kekuatan negara G20 dan juga BRIC (Brazil, Rusia, India dan China) permintaan akan komoditas juga menjadi tumbuh dan menggerakan roda ekonomi.

Penelitian ini ingin secara khusus membahas sebuah model CAPM dengan pendekatan sektor industri. CAPM ini juga dikenal dengan Capital Asset Pricing Model merupakan model yang paling sering diajarkan dalam studi keuangan. Adapun sektor industri yang akan diulas pada penelitian ini adalah sektor pertanian (Agriculture). Sektor ini pada akhir tahun 2011 memberikan gain sekitar $22.41 \%$ dibandingkan tahun sebelumnya. Selain itu motivasi utama penelitian ini mengulas sektor pertanian adalah Indonesia sendiri memiliki sumber daya alam yang sangat bagus dan memiliki sejarah panjang terkait dengan industri agribisnis ini. Oleh karena itu ada baiknya analisis ini dilakukan pada sektor ini terlebih dahulu sebelum sektor yang lainnya.

Model ini diperkenalkan oleh Sharpe dan Lintner (1964), dan tetap menjadi sebuah model yang paling populer bagi para praktisi dan akademisi keuangan berbicara mengenai risiko dan tingkat pengembalian. Dari beberapa penilitian terkait dengan CAPM sendiri ternyata memang masih ada pro dan kontra terhadap model ini. Model ini memiliki kekurangan dalam penerapan secara empiris. Akan tetapi model ini kuat secara teoritis. Selain itu beberapa penelitian juga telah dilakukan untuk mengamati fenomena return saham tersebut dan beberapa penelitian menawarkan beberapa 
variabel tambahan sebagai penjelas variasi return saham.

Banz (1981) memperkenalkan size-
effect untuk menjelaskan ternyata perusahaan dengan kapitalisasi kecil malah memiliki return yang cukup tinggi. Keim (1986) menemukan January-effect yang menyatakan bahwa terjadi anomali pada bulan Januari, untuk sesaat harga saham cenderung tinggi pada bulan tersebut. Paulo (2010) membuat sebuah penelitian khusus dalam menelaah kesalahan empiris CAPM dan menemukan banyak kesalahan dan rendahnya nilai $\mathrm{R}^{2}$ dari CAPM.

Hanya saja ternyata tidak semua temuan sejalan dengan penelitian tersebut. Kiky (2014) menemukan secara empiris ternyata CAPM memiliki nilai $\mathrm{R}^{2}$ yang tinggi. Hal ini dikarenakan analisis CAPM dilakukan dengan membentuk portofolio bulanan dari seluruh perusahaan yang terdaftar.

Tertarik akan dua temuan yang pro dan kontra tersebut maka penelitian ingin menguji lebih dalam mengenai pembuktian CAPM di Bursa Efek Indonesia dengan pendekatan sektor industri. Penelitian ini secara khusus ingin menelaah CAPM dengan membentuk portofolio khusus yang dikategorikan sesuai dengan sektor industri, khususnya sektor pertanian. Sehingga penelitian ini berharap menemukan sebuah benang merah apakah CAPM masih bisa tetap superior setelah dianalisis menggunakan pendekatan sektor industri.

Objek penelitian ini mengambil sampel dari perusahaan terbuka yang terdaftar pada Bursa Efek Indonesia selama periode 2005 hingga tahun 2011. Selain itu sampel perusahaan hanya terbatas pada sektor pertanian saja (agriculture). Penelitian ini melanjutkan penelitian Kiky (2014) dengan menggunakan pendekatan yang sedikit berbeda. Sampel dari perusahaan non keuangan dikeluarkan dengan alasan menghindari bias yang mungkin timbul sebagai akibat perbedaan struktur modal dari kategori tersebut, sehingga dengan sendirinya penelitian ini hanya meneliti 1 sektor industri dari 9 sektor industri yang ada. Kedelapan sektor yang akan diteliti dalam penelitian ini adalah sektor pertanian, pertambangan, industri dasar kimia, aneka industri, barang konsumsi, properti dan real estate, infrastrukturutilitas-transportasi, dan perdagangan-jasainvestasi.

\section{Tinjauan Literatur dan Hipotesis}

Return merupakan reward ataupun tambahan kekayaan bagi investor yang biasanya dibagi menjadi 2 komponen utama menurut Jones (2010) yaitu Yield dan Capital Gain (loss). Kedua komponen tersebut jika digabungkan menjadi Total Return yang persamaannya:

$$
\text { Return Saham }=\frac{P_{t}-P_{t-1}}{P_{t-1}}+\frac{D_{t}}{P_{t-1}}
$$

$\mathrm{Pt}=$ Harga Saham pada periode $\mathrm{t}$

Pt-1 = Harga Saham pada periode t-1

Dt $=$ Dividen Saham pada periode $\mathrm{t}$

Adapun Yield dalam saham dikenal juga dengan dividen yang dibagikan oleh perusahaan. Dan jika investor menjual sahamnya saat terjadi apresiasi, maka investor akan mendapatkan tambahan kekayaan dalam bentuk capital gain.

Teori pasar modal efisien menurut Husnan (2009) menyatakan pasar sempurna maka harga dari saham-saham yang diperdagangkan telah mencerminkan informasi yang relevan dan aktual. Dengan kata lain tidak ada lagi informasi rahasia atau tertutup dari perusahaan yang memungkinkan terjadi arbitrase sebagai akibat informasi yang tidak simetris. Selain itu harga saham juga merefleksikan informasi seperti pengumuman pertumbuhan laba dan pembagian dividen untuk tahun ini naik sehingga menurut teori pasar yang efisien maka harga saham perusahaan tersebut akan dengan cepat juga mengalami perubahan merespon 
informasi tersebut. Fama (1970) mengelompokan pasar modal efisien ini menjadi 3 bentuk:

\section{Weak Form}

Merupakan bentuk pasar di mana hargaharga dari saham mencerminkan informasi di masa lalu. Akibatnya informasi yang ada sekarang masih kurang aktual sehingga dengan kata lain harga yang telah terjadi tidak dapat dijadikan pedoman untuk memprediksi harga di masa yang akan datang. Bentuk ini berkaitan dengan teori Kendall (1953) yaitu random walk yang menyatakan harga sekuritas terbentuk secara acak.

\section{Semi Strong Form}

Merupakan bentuk pasar yang harga-harga dari sekuritasnya telah mencerminkan semua informasi yang telah dipublikasikan termasuk informasi pada laporan keuangan. Jogiyanto (2010) menyatakan informasi tersebut dapat berupa:

1. Informasi yang dipublikasikan yang hanya mempengaruhi harga sekuritas dari perusahaan yang mempublikasikan informasi tersebut. Informasi ini contohnya adalah informasi yang berhubungan dengan perusahaan emiten (corporate event) seperti pengumuman laba, pengumuman pembagian dividen, pengumuman pengembangan produk baru, pengumuman merger dan akuisisi, pengumuman metode akuntansi juga pengumuman pergantian pemimpin perusahaan.

2. Informasi yang dipublikasikan yang mempengaruhi harga sekuritas sejumlah perusahaan. Informasi ini dapat berupa peraturan pemerintah atau peraturan dari regulator yang hanya berdampak pada harga-harga sekuritas perusahaan yang terkena regulasi tersebut. Contoh untuk informasi ini adalah regulasi untuk meningkatkan kebutuhan cadang (reserve requirement) yang harus dipenuhi oleh bank ataupun informasi terkait sektor industri tertentu.

Pada bentuk semi strong ini masih memungkinkan untuk mengambil keuntungan dari informasi rahasia yang bisa bocor dari dalam internal perusahaan.

\section{Strong Form}

Merupakan bentuk pasar yang harga-harga sekuritasnya telah secara penuh mencerminkan semua informasi termasuk informasi privat perusahaan. Dengan kata lain investor tidak dapat mengambil keuntungan tidak normal (abnormal return) karena telah memperoleh informasi privat dari dalam perusahaan. Sehingga pada bentuk strong ini, para trader tidak bisa mengambil keuntungan sebagai akibat informasi yang tidak simetris.

\section{Penelitian Fama}

menemukan bahwa ketiga bentuk pasar ini berhubungan satu sama lain. Hubungan ketiga bentuk pasar efisien ini berupa tingkatan yang kumulatif yaitu weak form merupakan bagian dari semi strong form dan strong form. Dengan kata lain pasar efisien strong form juga merupakan pasar efisien semi strong dan weak form.

Teori pasar efisien menjadi salah satu landasan teori utama dari penelitian ini. Berdasarkan teori ini peneliti berasumsi pasar sudah efisien sehingga harga yang sudah ada di pasar telah merefleksikan informasi yang terkadung dalam sekuritas tersebut. Sehingga itu bisa dijadikan acuan utama peneliti dalam menentukan return sekuritas. Telaah ini didasarkan pada fakta penelitian terdahulu yang dilakukan Fama \& French (1993) yang menggunakan harga saham untuk menghitung return saham yang diteliti.

Salah satu faktor penting yang perlu diperhatikan dalam melakukan investasi adalah risiko. Risiko sendiri dilambangkan dengan Beta yang merupakan pengukur volatilitas (volatility) return suatu sekuritas atau return 
portofolio terhadap return pasar, Jogiyanto (2010).

Berikut ini adalah model yang dikembangkan oleh Sharpe-Lintner-Black:

$$
R_{s}=R_{R F}+\left(R P_{m}\right) b i
$$

Di mana :

Rs = tingkat return portofolio

$\mathrm{RRF}=$ tingkat return aset bebas risiko

$\mathrm{RPm}=$ return market risk premium

bi = beta saham yang bersangkutan

CAPM merupakan model yang telah lama dikenal dalam ilmu keuangan. Model ini secara sederhana memperkenalkan bahwa sebuah tingkat pengembalian suatu sekuritas sebanding dengan market premium sekuritas yang sekuritas tersebut ditambah dengan tingkat pengembalian bebas risiko. Model ini pada awalnya diperkenalkan oleh Sharpe dan Lintner (1964) sebagai tindak lanjut dari penelitian Markowitz (1952) mengenai pembentukan portofolio efisien dan merupakan salah satu langkah awal yang ditempuh para akademisi dunia keuangan dalam menyusun sebuah teori mengenai penilaian aset. Model ini dikembangkan dengan asumsi para investor adalah orang yang rasional dan juga beberapa hal terkait dengan biaya transaksi yang mungkin terjadi dianggap nol.

Banz (1981) menyatakan bahwa ternyata perusahaan dengan ukuran kapitalisasi yang kecil memiliki risiko lebih tinggi sehingga cenderung memiliki return yang tinggi dibandingkan dengan perusahaan besar. Hasil analisa Banz selama periode 10 tahun menunjukan ada perbedaan yang sangat besar derajat dari koefisien dari faktor size. Hal ini dikenal juga dengan istilah size effect. Munculnya size effect ini menjadi pertanyaan bagi ekonom sebab tidak ada landasan teoritis terhadap faktor size tersebut. Model CAPM sendiri yang menjadi dasar untuk penilaian aset dan diajarkan pada berbagai sekolah bisnis ternyata secara empiris gagal. Hal ini tertulis dalam penelitian Paulo (2010) yang memuat daftar pembuktian empiris CAPM sejak tahun 2004. Daftar tersebut memuat penelitian Guo, H. (2004) yang menyatakan CAPM gagal untuk menjelaskan prediksi return saham, Arnott, R.D. (2005) menyatakan bahwa CAPM tidak lolos dari pengamatan secara empiris dan secara fakta tidak tepat baik empiris maupun teoritis, Bartholdy dan Peare (2005) tidak mampu secara empiris memberikan verifikasi CAPM sebagai estimasi expected return saham, Lewellen, J. dan Nagel (2006) baik conditional CAPM yang menekankan kenaikan risiko pada kondisi terburuk (krisis) maupun unconditional CAPM sama-sama tidak mampu menjelaskan expected return saham.

Sebenarnya temuan anomali terkait dengan CAPM ini telah lama ditemukan, selain Banz, Keim (1983) menemukan tingkat pengembalian yang relatif tinggi pada bulan tertentu, dalam kasusnya yakni bulan Januari. Temuan Keim ini dikenal dengan Januari Efek. Roll (1988) juga memberikan kritik dan secara empiris nilai $\mathrm{R}^{2}$ dari model CAPM hanya sebesar 0.35 dengan penggunaan data bulanan. Sedangkan nilai itu turun menjadi lebih kecil lagi dan menjadi sebesar 0.2 dengan penggunaan data harian.

Selain itu mulai muncul beberapa tandingan model CAPM seperti model APT yang diperkenalkan Ross (1976), model 3 faktor yang diperkenalkan Fama \& French (1992) dan bahkan model 3 faktor sendiri berkembang menjadi model 4 faktor yang diperkenalkan Carhart (2002).

Hanya saja sekalipun mengalami banyak tantangan dan kritik, Kiky (2014) berhasil membuktikan secara empiris ternyata CAPM masih valid. Tentu saja temuan ini didasarkan pada data return saham yang dikombinasikan dalam portofolio secara bulanan. Hasilnya adalah nilai $\mathrm{R}^{2}$ yang sangat tinggi. Hanya saja terdapat beberapa masukan terkait dengan 
penelitian tersebut sehingga pengembangan selanjutnya adalah membentuk portfolio sesuai dengan sektor industri dari saham-saham tersebut. Tantangan terbesarnya adalah apakah model CAPM masih secara konsisten menunjukan nilai $\mathrm{R}^{2}$ yang tinggi? Apakah model yang secara fundamental menjadi kunci utama pada setiap pelajaran keuangan menjadi error secara empiris setelah dipecahkan secara spesifik untuk kategori industri pertanian yang ada. Apa yang menjadi penyebab hal tersebut dan penelitian ini bertujuan menjawab keabsahan model CAPM sekali lagi.

Terdapat dua hipotesis yang akan diuji pada penelitian ini yaitu;

$\mathrm{H}_{1}=$ terdapat pengaruh excess return pasar terhadap excess return portofolio sektor industri.

$\mathrm{H}_{2}=$ model CAPM memiliki nilai $\mathrm{R}^{2}$ yang cukup tinggi (>50\%).

\section{III.Metode Penelitian}

Objek penelitian ini adalah model CAPM yang diuji dengan menggunakan analisis regresi. Data harga saham harian digunakan untuk mencari return sahamsaham yang dibentuk dalam kategori sektor industri. Sampel penelitian diambil dari perusahaan yang terdaftar di BEI dengan kategori industri pertanian selama periode 2005 hingga tahun 2011. Data harian saham dan IHSG harian diperoleh dari ISMD (Indonesian Security Market Database), untuk data risk free rate penulis mengambil dari laporan bulanan Bank Indonesia berupa data SBI dari tahun 2005 sampai dengan 2011.

Berikut ini adalah langkah-langkah penyusunan penelitian:

1. Penelitian ini mengambil sampel dari perusahaan publik pertanian yang secara konsisten terdaftar di Bursa Efek Indonesia selama 7 tahun (2005 sampai 2011).

2. Data SBI akan dikelompokan bulanan dan IHSG akan dirata-rata selama satu bulan. Sehingga akan diperoleh 12 data SBI dan IHSG selama satu tahun periode penelitian.

3. Sampel perusahaan juga akan dikumpulkan sesuai dengan kategori sektor industrinya dan dibentuk kelompok portofolio sektor industri.

4. Variabel Dummy akan membantu untuk menganalisis pengaruh dari sektor industri tersebut.

5. Model akan dianalis menggunakan analisis regresi sederhana dan akan diukur nilai $\mathrm{F}$ test dan $\mathrm{t}$ test. Selain itu penelitian ini juga ingin menilai nilai $\mathrm{R}^{2}$ dari model CAPM

Model yang akan diuji pada penelitian ini adalah

Di mana :

Rs $-\mathrm{R}_{\mathrm{F}} \quad=$ Excess return portofolio

$\mathrm{RF} \quad=$ tingkat return aset bebas risiko

$\mathrm{R}_{\mathrm{m}}-\mathrm{R}_{\mathrm{F}} \quad=$ Excess return market risk premium

$\mathrm{a}_{\mathrm{i}} \quad=$ konstanta

$\mathrm{b}_{\mathrm{i}} \quad=$ beta saham

$\mathrm{e}_{\mathrm{i}} \quad=$ error

$$
R_{s}-R_{R F}=a_{i}+b_{i}\left(R_{m}-R_{R F}\right)+e_{i}
$$




\section{IV.Hasil dan Pembahasan}

\section{Analisis Deskriptif}

Berdasarkan hasil statistik deskriptif, terlihat pola pada tahun 2009 sektor pertanian mengalami kenaikan yang cukup tinggi. Hal ini sejalan dengan temuan pada penelitian Kiky (2014), yang menemukan gain yang tinggi pada portofolio semua sampel perusahaan pada tahun 2005 sampai tahun 2011. Ditemukan bahwa sektor pertanian ternyata sejalan dengan pergerakan portofolio tersebut. Selain itu dari sampel yang membentuk portofolio ini ternyata kontribusi terbesar didistribusikan oleh UNSP. UNSP merupakan salah satu perusahaan milik Bakrie yang bergerak dalam bidang agribisnis. Pada umumnya pergerakan perusahaan milik Bakrie ini memang perlu dicermati dan memiliki pergerakan yang cukup drastis baik kenaikan ataupun penurunan yang terjadi.

Tabel 4.1. Tabel Ri Bulanan

\begin{tabular}{cccccccc}
\hline Bulan & 2005 & 2006 & 2007 & 2008 & 2009 & 2010 & 2011 \\
\hline 1 & 0.04 & -0.01 & -0.00 & 0.00 & 0.06 & 0.00 & -0.00 \\
2 & 0.01 & 0.01 & 0.00 & 0.01 & 0.07 & -0.00 & -0.01 \\
3 & 0.01 & 0.01 & 0.00 & -0.01 & 0.08 & 0.00 & 0.00 \\
4 & -0.01 & 0.01 & 0.01 & -0.00 & 0.10 & 0.00 & 0.00 \\
5 & -0.00 & -0.00 & 0.00 & 0.01 & 0.11 & -0.00 & 0.00 \\
6 & 0.02 & -0.00 & -0.00 & 0.00 & 0.12 & 0.00 & -0.01 \\
7 & 0.01 & -0.01 & 0.00 & -0.01 & 0.00 & 0.00 & 0.00 \\
8 & -0.00 & 0.00 & -0.01 & -0.01 & 0.00 & 0.00 & -0.00 \\
9 & 0.00 & -0.00 & 0.01 & -0.01 & -0.00 & 0.00 & -0.00 \\
10 & 0.00 & 0.00 & 0.00 & -0.02 & 0.00 & 0.01 & 0.00 \\
11 & 0.00 & 0.00 & 0.00 & 0.00 & 0.00 & 0.00 & 0.00 \\
12 & 0.00 & 0.01 & 0.00 & 0.00 & 0.00 & 0.00 & 0.00 \\
\hline
\end{tabular}

Selain itu perusahaan AALI milik Astra Grup, IIKP, LSIP dan TBLA juga merupakan sampel perusahaan yang cukup aktif selama tahun berjalan. Untuk sampel yang lain seperti BTEK,CPDW, dan DSFI mengalami beberapa periode non aktif. Dari total sampel 7 perusahaan ternyata ada 4 perusahaan yang cukup konsisten aktif dalam perdagangan $(>50 \%)$.

Tabel 4.2. Tabel Rm Bulanan

\begin{tabular}{cccccccc}
\hline Bulan & 2005 & 2006 & 2007 & 2008 & 2009 & 2010 & 2011 \\
\hline 1 & 0.002 & 0.003 & -0.001 & -0.002 & -0.001 & 0.001 & -0.004 \\
2 & 0.001 & 0.000 & 0.000 & 0.002 & -0.002 & -0.001 & 0.001 \\
3 & 0.000 & 0.003 & 0.002 & -0.005 & 0.005 & 0.004 & 0.003 \\
4 & -0.002 & 0.006 & 0.004 & -0.003 & 0.009 & 0.003 & 0.002 \\
5 & 0.003 & -0.004 & 0.002 & 0.003 & 0.006 & -0.003 & 0.000 \\
6 & 0.001 & 0.000 & 0.001 & -0.002 & 0.003 & 0.002 & 0.001 \\
7 & 0.003 & 0.002 & 0.004 & -0.001 & 0.007 & 0.002 & 0.003 \\
8 & -0.005 & 0.003 & -0.003 & -0.003 & 0.001 & 0.000 & -0.004 \\
9 & 0.001 & 0.003 & 0.004 & -0.008 & 0.003 & 0.008 & -0.003 \\
10 & -0.001 & 0.002 & 0.006 & -0.019 & -0.002 & 0.002 & 0.003
\end{tabular}




\begin{tabular}{cccccccc}
11 & 0.002 & 0.004 & 0.001 & 0.000 & 0.001 & -0.001 & -0.001 \\
12 & 0.003 & 0.003 & 0.001 & 0.005 & 0.002 & 0.002 & 0.001 \\
\hline
\end{tabular}

Pola yang sama juga ternyata ditemukan pada IHSG secara rata-rata per bulan. Kondisi pasar Indonesia ternyata menunjukan sinyal yang positif pada tahun 2009 sedangkan pada tahun 2008 memberikan sinyal yang negatif sebagai respon terhadap ekonomi dunia yang sedang buruk.

Adapun dibawah ini peneliti juga melampirkan grafik garis dari paparan tabel di atas untuk memudahkan pembaca melihat pola yang dibahas di atas.

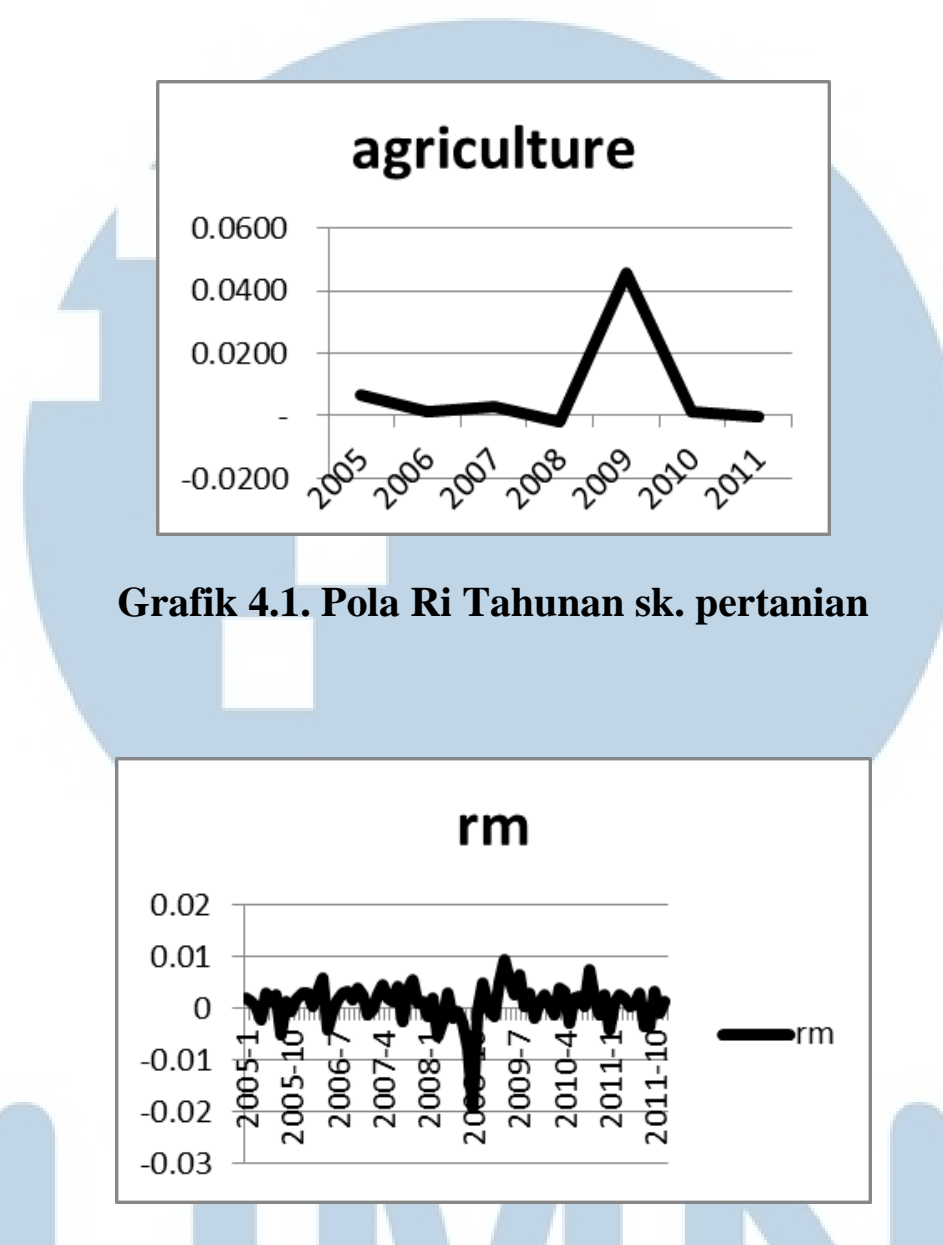

\section{Grafik 4.2. Pola Rm Bulanan}

Membandingkan kedua grafik di atas, maka dapat terlihat resistensi dari sektor pertanian cukup baik ketika pasar mengalami resesi pada tahun 2008. Hanya saja jika ditelaah per kategori perusahaan, perusahaan yang pada umumnya aktif dalam perdagangan akan memiliki pola yang sama dengan market. Perusahaan tersebut adalah AALI, IIKP, LSIP dan TBLA. Sedangkan untuk perusahaan UNSP memiliki return yang cukup tinggi sehingga membuat pola sektor pertanian sedikit berbeda dengan pola market. Secara fundamental sektor ini adalah sektor paling basic yang sifatnya menyediakan komoditas dan barang penunjang industri konsumsi. Kebutuhan akan pangan masih merupakan kebutuhan utama sehingga bisa dikatakan penyebab sektor ini memiliki resistensi yang baik adalah karena karakteristik dari sektor tersebut 


\section{Uji Hipotesis \& Pembahasan}

Adapun hipotesis yang akan diuji adalah sebagai berikut:

$\mathrm{H}_{01}=$ tidak terdapat pengaruh signifikan excess return pasar terhadap excess retur portofolio.

$\mathrm{H}_{\mathrm{a} 1}=$ terdapat pengaruh signifikan excess return pasar terhadap excess return portofolio.

$\mathrm{H}_{02}=$ model CAPM tidak memiliki nilai $\mathrm{R}^{2}$ yang cukup tinggi. (>50\%)

$$
\begin{gathered}
\mathrm{H}_{\mathrm{a} 2}=\text { model CAPM memiliki nilai } \mathrm{R}^{2} \\
\text { yang cukup tinggi. }(>50 \%)
\end{gathered}
$$

Kedua hipotesis tersebut akan diuji menggunakan $\mathrm{F}$ test dan $\mathrm{t}$ test untuk hipotesis pertama dan pada hipotesis kedua peneliti langsung menilai nilai $\mathrm{R}^{2}$ dari model CAPM.

Berikut ini adalah tabel hasil analisis hipotesis terhadap model CAPM:

Tabel 4.3. Hasil Analisis Hipotesis

\begin{tabular}{lll}
\hline Indikator & value & Sig \\
\hline F test & 88.63 & 0.000 \\
$\mathrm{t}$ test & 9.41 & 0.000 \\
\hline & $\mathrm{t}$ & $\mathrm{sig}$ \\
\hline Intercept & 0.020 & 0.067 \\
Slope b & 1.15 & 0.000 \\
$\mathrm{R}^{2}$ & 0.519 & \\
\hline
\end{tabular}

Berdasarkan hasil dari regresi tersebut ternyata peneliti memiliki cukup bukti untuk menolak Ho. Sehingga dapat dikatakan ternyata market premium memiliki pengaruh yang signifikan terhadap return portofolio sektor pertanian. Selain itu nilai $F$ test juga menunjukan hasil yang serupa. Hanya saja karena model ini hanya terdiri atas satu variabel saja, hasil $F$ mengkonfirmasi ternyata penelitian ini tidak menunjukan error.

Penelitian ini masih dapat membuktikan secara empiris ternyata CAPM tidak error. Hanya saja nilai dari $\mathrm{R}^{2}$ dari model yang disusun dari data yang dibentuk berdasarkan portofolio sektor pertanian menunjukan nilai yang lebih rendah dibandingkan portofolio bulanan. Dalam menerangkan variasi return ada sekitar $51.9 \%$ variasi return yang dapat dijelaskan oleh model CAPM dengan tingkat error sebesar $48.1 \%$. Nilai variasi CAPM turun drastis jika dibandingkan hasil penelitian Kiky (2014) yang membentuk portofolio bulanan yang mana penurunan nilai $\mathrm{R}^{2}$ hingga sampai $40 \%$. Error yang terjadi pada sektor industri pertanian ini cukup tinggi.

Temuan ini tentu saja menimbulkan sebuah pertanyaan. Apakah memang CAPM sangat superior jika pada portofolio pasar secara keseluruhan saja? Peneliti memiliki beberapa dugaan terkait dengan temuan ini.

Dugaan pertama mengkonfirmasi pertanyaan penelitian Kiky (2014) sebelumnya yakni karena data sampel dari penelitian ini dibentuk berdasarkan portofolio bulanan yang terdiri dari 200 perusahaan maka akibatnya adalah return rata-rata dari sekuritas tersebut relatif kecil sebagai akibat dari penggabungan dari berbagai macam perusahaan. Sehingga pada penelitian ini terbukti bahwa CAPM menjadi kurang valid jika diterapkan pada perusahaan dengan sektor industri yang spesifik.

Menurut peneliti mungkin ada baiknya penelitian ini dikembangkan menjadi penelitian yang berbasis pada sekuritas tertentu saja yang mana maksudnya adalah CAPM langsung diterapkan pada perusahaan tertentu saja 
tanpa membentuk portofolio terlebih dahulu. Dengan membuat data return yang hanya berbasis pada sekuritas tertentu maka mungkin penelitian tersebut akan mengkonfirmasi error atau anomali yang lebih tinggi sesesuai dengan kritik pada penelitian terdahulunya.

Temuan peneliti juga menyimpulkan sektor pertanian, jika kita membentuk portofolio berdasarkan sektor ini saja, masih memiliki pola yang sama dengan market premium. Selain itu ternyata hasil deskriptif juga membuktikan ternyata sektor ini cukup baik saat terkena imbas krisis ekonomi global pada tahun 2008. Hal ini disebabkan kategori atau karakter dari sektor ini yang bersifat industri dasar ataupun pangan yang pasti dicari oleh konsumen karena merupakan kebutuhan primer.

Hanya saja tentunya hal ini perlu dikritisi sebab masih butuh ada konfirmasi lain dari sektor sejenis seperti sektor barang konsumsi (Consumer Goods), yang mana jika memang seperti dugaan penulis maka seharusnya sektor barang konsumsi juga memiliki pola yang sama atau bahkan menunjukan resistensi yang lebih baik selama masa krisis. Hanya saja tentunya ini menjadi sebuah masukan untuk pengembangan riset ini dengan membandingkan sampel dari sektor tersebut.

Kesimpulan akhir dari temuan ini adalah ternyata CAPM masih terbukti cukup baik dalam menerangkan return sekalipun kemampuan penjelasnya sekitar $51.9 \%$ saja.

\section{Simpulan, Keterbatasan, dan Saran}

Temuan penelitian ini membuktikan bahwa CAPM secara empiris pada sektor pertanian ternyata cukup baik tapi masih jauh jika dibandingkan portofolio bulanan semua sampel. Bahkan error yang ditemukan menjadi lebih besar, dengan nilai $48.1 \%$. Tentunya temuan ini mengkonfirmasi temuan Kiky (2014) serta kritiknya untuk membentuk sebuah portofolio yang lebih spesifik dan unik sehingga diperoleh aplikasi CAPM sesuai dengan perusahaan yang dibentuk diteliti. Akibatnya CAPM sebenarnya hanya mampu menangkap risiko pasar secara keseluruhan tapi tidak secara spesifik pada perusahaan tertentu.

Saran untuk penelitian selanjutnya ada baiknya temuan ini dikonfirmasi dengan membandingkan dengan pembentukan data portofolio dengan karakteristik yang mirip seperti sektor barang konsumsi.

Selain itu model CAPM ada baiknya jika mulai dibandingkan dengan model yang lain seperti APT, Fama French ataupun Carhart Four Factor Model pada sektor industri pertanian. Apakah memang ada faktor size, value atau momentum yang lebih baik dalam menerangkan varian return saham dibandingkan market premium setelah aplikasinya pada sektor industri.

Pengembangan penelitian ini juga terbuka untuk penelitian terkait dengan anomali ataupun penelitian keuangan tentang psikologi pasar. Hal ini tentunya akan erat kaitannya dengan teori tentang behavioral finance.

\section{REFERENSI}

Arifin, Zaenal. 2005. Teori Keuangan \& Pasar Modal. Yogyakarta: Ekonisia.

Banz, Rolf W. 1981. "The Relationship Between Return and market Value of Common Stocks". Journal of Financial Economics, $9,3-18$.

Bickford, Joel D. 2003. "Fama/French Three Factor Model". Bickford Investment Management Service, Bickfordinvestment. Database online. Eugene Fama DFA Conference. 
Connor, Gregory \& Sanjay Sehgal. 2001. "Test of the Fama and French Model in India". Working Paper, University of Dehli, India.

Corrado, Charles J. 2009. Fundamental of Investment Valuation and Management. America: McGraw Hill Irwin.

Fama, Eugene F. \& Kennenth R. French. 1992. "The Cross-Section of Expected Stock Returns". Journal of Finance, 47, 427 - 465.

Fama, Eugene F. \& Kennenth R. French. 1993. " Common Risk Factors in the Return on Stock and Bonds". Journal of Financial Economics, $33,3-56$.

Fama, Eugene F. \& Kennenth R. French. 1996. "Multifactor Explanations of Asset Pricing Anomalies". Journal of Finance, 51, $55-84$.

Fama, Eugene F. \& Kennenth R. French . 1998. "Value Versus Growth: The International Evidence". Journal of Finance , 53, 1975-1999.

Gharghori, Philip. 2007. " Are the FamaFrench Factor Proxying Default Risk?", Australian Journal of Management, 32, 223-248, ABI/Uniform Research. Database on-line. Proquest.

Gitman, Lawrence J. 2009. Principle of Managerial Finance. California: Pearson.

Gujarati, Damodar. 2004. Basic Econometrics. McGrawHill.

Hardianto, Damar \& Suherman. 2007. "Pengujian Fama-French ThreeFactor Model di Indonesia". Jurnal Keuangan dan Perbankan, 13, 198-208.
Hartono, Jogiyanto. 2010. Teori Portofolio dan Analisis Investasi. Yogyakarta: BPFE UGM.

Homsud, Nopbhanon, dkk. 2009. "A Study of Fama and French Three Factor Model in Stock Exchange of Thailand". International Research Journals of Finance and Economic, 25, 31-49, EuroJournals Publishing. Database on-line. Proquest.

Husnan, Suad. 2009. Dasar-Dasar Teori Portofolio dan Analisis sekuritas. Yogyakarta: UPP STIM YKPN.

Jones, Charles P. 2005. Investment Principles and Concept. North Carolina State: John Wiley.

Kiky, Andreas. 2014. "Studi Empiris CAPM pada Bursa Efek Indonesia Tahun 2005 sampai Tahun 2011". Jurnal Bina Manajemen. 2.

Lam, Keith S. K., Frank K. Li \& Simon M. S. So. 2010. "On Validity of the Augmented Fama and French's (1993) Model: Evidance from the Hong Kong Stock Market". Rev Quant Finan Acc, $35,89-111$.

Li, Bin. Bejamin Liu \& Eduardo Roca. 2011. "Stock Return and Consumption Factors in the Australian Market: CrossSectional Tests".Australian Journal of Management, 36, 247266.

Lind, Douglas A., William G. Marchal, Samuel A. Wathen. 2008. Statistical Techniques in Business \& Economics with Global Data Sets. International Edition: McGraw Hill.

Markowitz, H. 1952. Portfolio Selection. The Journal of Finance, 7, 77-91. 
Moy, Ronald L. 2007. "Investor and Markets: Portfolio Choices, Asset Prices and Investment Advice. Financial Analysis Journal, 63, 84-84.

Paulo, S. "The United Kingdom's Companies Act of 2006 and the Capital Asset Pricing Model". International Journal of Law and Management, 52, 253-264.

Petrus. 2006. "Pengujian The Fama and French Model di BEJ pada Periode 2002 Sampai Dengan 2004”. Thesis. Jakarta: IBII.

Ross, Stephen A. 1976. "The Arbitrage Theory of Capital Asset Pricing". Journal of Economic Theory, 13, $341-360$.

Saputra, Dede Irawan \& Umi Murti. 2008. "Perbandingan Fama and French Three Factor Model dengan Capital Asset Pricing Model".
Jurnal Riset Akuntansi dan Keuangan, 4, 132-145.

Sharpe, William F. 1964. "Capital Asset Prices: A Theory of Market Equilibrium under Condition of Risk". Journal of Finance , 19, $425-442$.

Sunyoto, Danang. 2011. Analisis Regresi dan Uji Hipotesis. Yogyakarta: CAPS.

Tandelin, Eduardus. 2010. Portofolio dan Investasi Teori dan Aplikasi. Yogyakarta: Kanisius.

Walid, Elhaj Mabrouk . 2009. "New Evidence on Risk Factors, Characteristics and the CrossSectional Variation of Japanese Stock Returns". Asia-Pasific Finan Market, 16, 33 - 50.

Zubir, Zalmi. 2011. Manajemen Portofolio Penerapan dalam Investasi Saham. Jakarta: Salemba Empat.
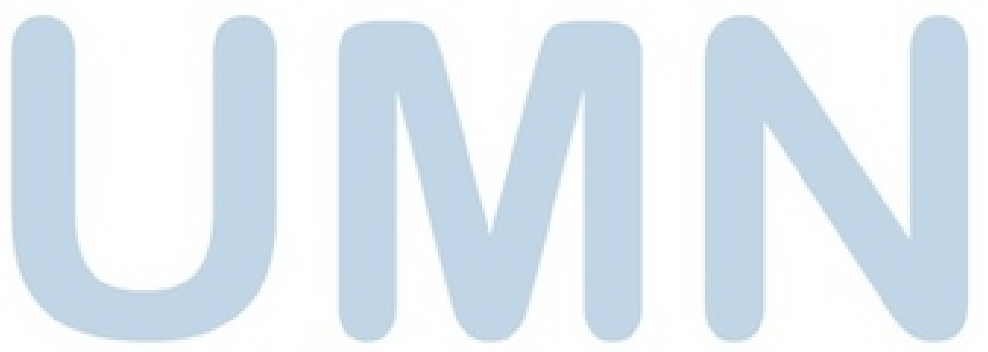